\title{
Physiological and morphological responses of Lead or Cadmium exposed Chlorella sorokiniana 211-8K (Chlorophyceae)
}

\author{
Simona Carfagna ${ }^{1}$, Nicola Lanza ${ }^{1}$, Giovanna Salbitani ${ }^{1}$, Adriana Basile ${ }^{1}$, Sergio Sorbo ${ }^{2}$ and Vincenza Vona ${ }^{1 *}$
}

\begin{abstract}
The heavy metal pollution in soils and aquatic environments is a serious ecological problem. In the green-microalga Chlorella sorokiniana 211-8K (Chlorophyceae) exposed to ions of lead (Pb) and cadmium (Cd) we studied the metabolic responses to the toxicity of these two heavy metals. Our data indicate that both the pollutants alter the alga cell ultrastructure and its physiological characteristics (growth, photosynthesis, respiration, enzyme activities). The toxic effects of the two metals resulted time-dependent to the exposure. After $24 \mathrm{~h}$ of treatment with $250 \mu \mathrm{M}$ $\mathrm{Pb}$ or $\mathrm{Cd}$, photosynthesis was inhibited until to 77 and $86 \%$, however respiration was strongly enhanced up to 300 and $350 \%$, respectively. In the algal cells $\mathrm{Pb}$ or Cd exposure induced a reduction in the content of the total chlorophylls and a decrease of the soluble protein levels, significantly compromising the growth, particularly in cultures cadmium-treated. We report data on ultrastructural changes induced by the two heavy metals; they affected overall chloroplast ultrastructure of the alga. Most importantly, the O-acetyl-L-serine(thiol)lyase (OASTL) activity was appreciably increased after only $2 \mathrm{~h}$ of $\mathrm{Cd}$ exposure, indicating the existence of a link between the metal contamination and cysteine synthesis. Then, Chlorella sorokiniana cells seem to better tolerate high concentrations of $\mathrm{Pb}$ while appear to be more sensitive to $\mathrm{Cd}$ ions. These results provide some additional information that can lead to better understand consequences of heavy metal poisoning in microalgae.
\end{abstract}

Keywords: Chlorella sorokiniana, Heavy metals, OASTL activity, Photosynthesis, Respiration, TEM

\section{Introduction}

Metals occur naturally, and several of them are essential components of global ecosystems. The development of human activities and industrialization has led to an increased accumulation of metals in the environment. Among the principal sources of metal pollution, there are the use of fertilizers and pesticides in agriculture (Hanikenne 2003). The contamination by heavy metals has become a serious problem because they could enter into food chains.

Microalgae, the primary producers at the base of the aquatic food chain, are the first target affected by heavy metal pollution. In microalgae trace concentrations of heavy metals are necessary as co-factor of enzymatic reactions, but high level of them could be extremely toxic

\footnotetext{
* Correspondence: vona@unina.it

'Dipartimento di Biologia, Università di Napoli Federico II, Via Foria 223,

I-80139 Naples, Italy

Full list of author information is available at the end of the article
}

(Travieso et al. 1999). Lead (Pb) and cadmium (Cd), two non-essential and toxic heavy metals for many living organisms, accumulate in algae (Debelius et al. 2009; Bajguz 2011). In fact, microalgae could be used to clean up contaminated water and waste streams by removing metals from soil and sediments, or solubilizing them in order to facilitate their extraction (Yoshida et al. 2006). Algae possess extracellular and intracellular mechanisms to prevent metal toxicity (Scheidegger et al. 2011). Metal uptake into algal cells is limited by lowering the metal bioavailability through excretion of non-specific ligands (Soldo et al. 2005) or by altering concentration and affinity of metal carrier proteins. Mostly important, microalgae provide important informations for predicting the environmental impact of heavy metal pollution (Akira et al. 2005).

Studies in plants (Benavides et al. 2005; Sharma and Dubey 2005) and algae (Szivak et al. 2009) have revealed that $\mathrm{Pb}$ and $\mathrm{Cd}$ are strongly phytotoxic, causing growth inhibition and even death (Deckert 2005); moreover, $\mathrm{Pb}$ 
induces toxic effects on protonema development and ultrastructure in the moss (Basile et al. 2008). In general, the toxic effects of metal pollutants in plant cell are related to their strong reactivity, resulting in inhibition of enzyme activity and oxidative damage. For these reasons, heavy metal ions are present in the cytoplasm mostly in a bound form (Sirko and Gotor 2007). To avoid oxidative damage, plant cells contain various antioxidant defence systems, enzymatic and non-enzymatic, designed to tightly control the concentration of ROS. Glutathione (GSH), a tripeptide containing cysteine (Cys), plays a crucial role in cellular protection (Sirko and Gotor 2007).

In the alga Scenedesmus vacuolatus, the exposure to $\mathrm{Pb}$ lowers GSH content and PC production, while $\mathrm{Cd}$ act as a strong inducer of PC synthesis. The same has been also observed in response to other metals and metalloids (Le Faucheur et al. 2006).

For this study we have chosen the alga Chlorella sorokiniana, that lives in fresh water but also in soils, (Yoshida et al. 2006; Chader et al. 2011), for its high capacity of adaptation during abiotic stress and its rapid growth rate (Carfagna et al. 2011a). In the present work, we focused on metabolic responses of the algal cells to $\mathrm{Cd}$ and $\mathrm{Pb}$, two important and widespread environmental pollutants. In this study, we assessed the effect of $\mathrm{Cd}$ and $\mathrm{Pb}$ at $250 \mu \mathrm{M}$ on growth and physiological parameters after 2 and $24 \mathrm{~h}$ of treatments. For the experiments we used the concentration of $250 \mu \mathrm{M}$, because at lower levels $(50$ and $100 \mu \mathrm{M})$ of $\mathrm{Pb}$ and $\mathrm{Cd}$ there is no significant effects (data not shown) on the algal response.

\section{Results}

\section{Effect of $\mathrm{Pb}$ and $\mathrm{Cd}$ on algal growth}

The effect of exposure to either $\mathrm{Pb}$ or $\mathrm{Cd}$ on the growth of Chlorella sorokiniana is shown in Figure 1. The control cells exhibited a growth rate $(\mu)$, calculated in exponential growth phase, of $3.16 \mathrm{~d}^{-1}$. $\mathrm{Pb}$ or $\mathrm{Cd}$ exposure caused a decrease of growth rate at 2.2 and $1.65 \mathrm{~d}^{-1}$, respectively.

\section{Effect of $\mathrm{Pb}$ and $\mathrm{Cd}$ on photosynthetic rate}

The photosynthetic rate in control cells of $C$. sorokiniana was initially $3.2 \pm 0.26 \mathrm{mmol} \mathrm{O}_{2} \mathrm{~mL}^{-1} \mathrm{PCV} \mathrm{h}^{-1}$. In the $\mathrm{Pb}$ treated cells, this activity was significantly reduced to $59 \%$ respect to control, reaching a value of $1.89 \pm 0.25 \mathrm{mmol}$ $\mathrm{O}_{2} \mathrm{~mL}^{-1} \mathrm{PCV} \mathrm{h}{ }^{-1}$ after $2 \mathrm{~h}$ exposure to the metal. The photosynthesis declined progressively in time up to a value of $0.73 \pm 0.05 \mathrm{mmol} \mathrm{O}_{2} \mathrm{~mL}^{-1} \mathrm{PCV} \mathrm{h}^{-1}$, showing an inhibition of $77 \%$, after $24 \mathrm{~h}$ exposure.

$\mathrm{Cd}$ supply to the cells caused a strong decrease in photosynthetic activity that decreased by $77 \%$ after $2 \mathrm{~h}$ of treatment reaching the value of $0.73 \pm 0.1 \mathrm{mmol} \mathrm{O}_{2} \mathrm{~mL}^{-1}$ $\mathrm{PCV} \mathrm{h}^{-1}$. Thereafter, the decline continued, and at $24 \mathrm{~h}$, the photosynthetic rate drastically dropped to $0.44 \pm 0.03$

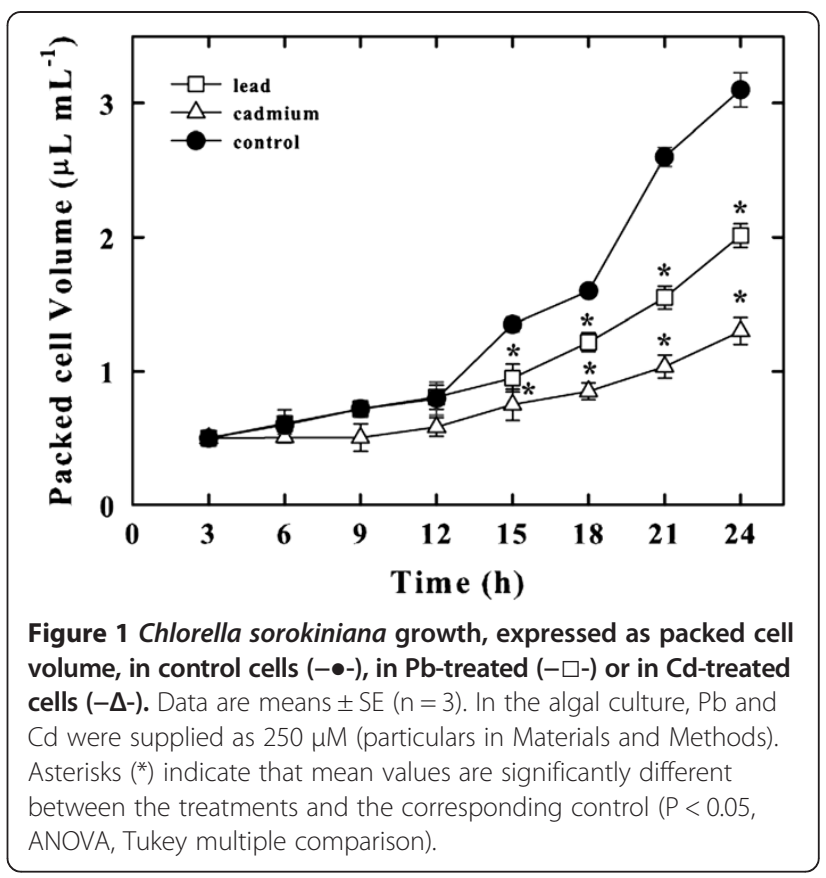

$\mathrm{mmol} \mathrm{O}_{2} \mathrm{~mL}^{-1} \mathrm{PCV} \mathrm{h}{ }^{-1}$, which was $14 \%$ of the control value (Figure 2).

Inhibition of photosynthesis was significantly greater in $\mathrm{Cd}$-treated cells than in Pb-treated ones after $2 \mathrm{~h}$.

\section{Effect of $\mathrm{Pb}$ and $\mathrm{Cd}$ on respiratory rate}

The respiratory oxygen consumption occurred in control cells at the rate of $0.13 \pm 0.02 \mathrm{mmol} \mathrm{O}_{2} \mathrm{~mL}^{-1} \mathrm{PCV} \mathrm{h}^{-1}$ (Figure 3) and significantly increased upon $\mathrm{Pb}$ or $\mathrm{Cd}$ supply resulting $0.39 \pm 0.05$ and $0.42 \pm 0.06 \mathrm{mmol} \mathrm{O}_{2} \mathrm{~mL}^{-1}$ $\mathrm{PCV} \mathrm{h}^{-1}$ after $2 \mathrm{~h}$, respectively. Even $24 \mathrm{~h}$ after the exposure to $\mathrm{Pb}$ or $\mathrm{Cd}$, the respiratory rate was still stimulated

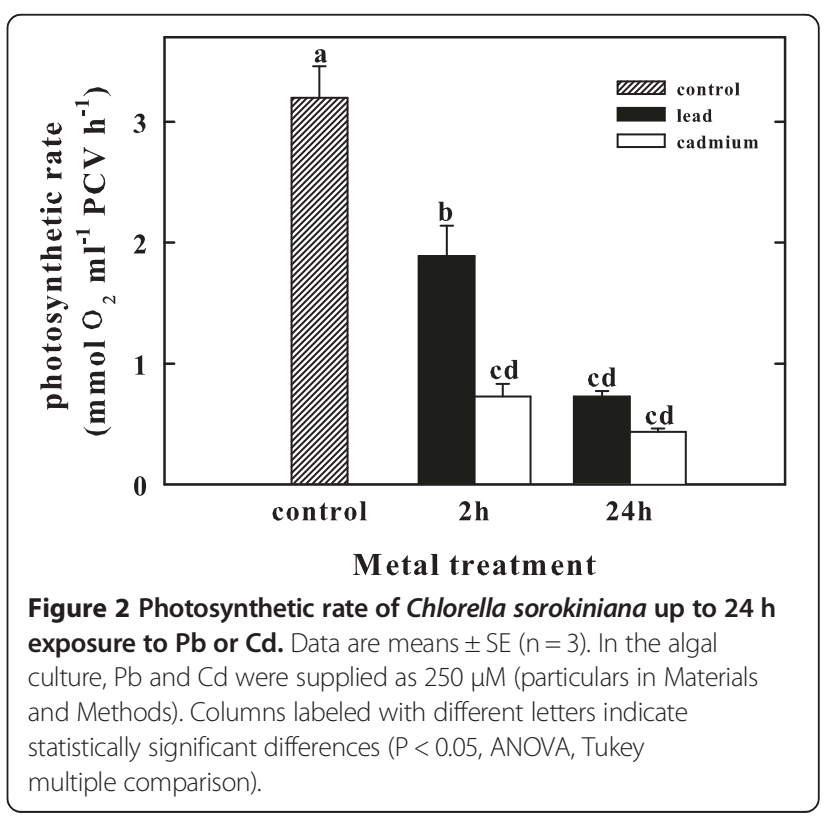




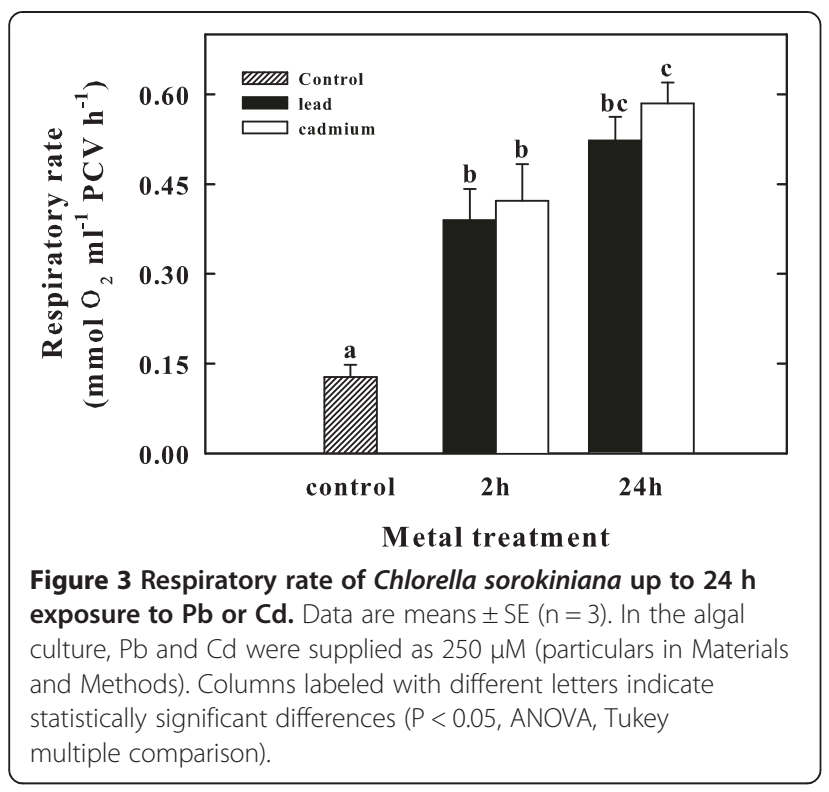

by 4- or 4.5 -fold, respectively. Again, the effect of $\mathrm{Cd}$ on respiration was greater than that of $\mathrm{Pb}$.

\section{Effect of $\mathrm{Pb}$ and $\mathrm{Cd}$ on chlorophyll content}

Levels of $\mathrm{Chl}$ were determined in $\mathrm{Pb}$ or $\mathrm{Cd}$ - treated $C$. sorokiniana cells. The effects of $\mathrm{Pb}$ or $\mathrm{Cd}$, on $\mathrm{Chl} a$ and total Chl contents after 2 and $24 \mathrm{~h}$ exposures are shown in Table 1. The Chl ( $a$ and total) contents decreased at 2 and $24 \mathrm{~h}$ of treatment, compared with the control, exhibiting a similar trend in variation upon $\mathrm{Pb}$ and $\mathrm{Cd}$ exposure. The highest drop in Chl concentration occurred after $24 \mathrm{~h}$ of exposure to both metals.

\section{Effect of $\mathrm{Pb}$ and $\mathrm{Cd}$ on total protein content}

The soluble protein contents strongly decreased during $\mathrm{Pb}$ or $\mathrm{Cd}$ exposure (Figure 4). The protein levels in $\mathrm{Pb}-$ treated cells decreased, at 2 and 24 h exposure, by $35 \%$ and $61 \%$, compared to the control. In Cd-treated cells, at 2 and $24 \mathrm{~h}$ exposure, the total protein levels were very low, being only 48 and $35 \%$ of the control cells, respectively.

\section{Effect of $\mathrm{Pb}$ and $\mathrm{Cd}$ on OASTL activity}

The OASTL activity was determined in C. sorokiniana control cells and in $\mathrm{Pb}$ or $\mathrm{Cd}$ treated cells (Figure 5). The enzyme activity seems to be not influenced by lead

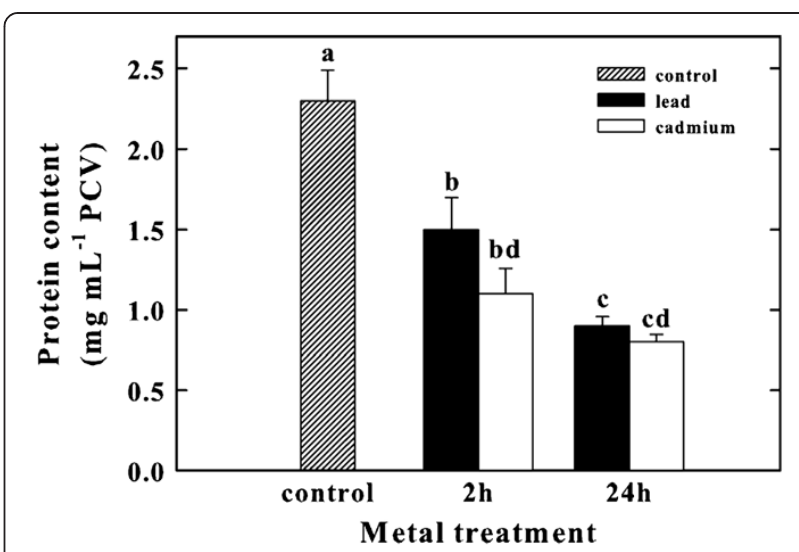

Figure 4 Effect of $\mathrm{Pb}$ or $\mathrm{Cd}$ on total protein content ( $\mathrm{mg} \mathrm{mL}^{-1} \mathrm{PCV}$ ) in Chlorella sorokiniana cells after $\mathbf{2}$ and $\mathbf{2 4} \mathbf{h}$. Data are means \pm SE $(n=3)$. In the algal culture, $\mathrm{Pb}$ and $\mathrm{Cd}$ were supplied as $250 \mu \mathrm{M}$ (particulars in Materials and Methods). Columns labeled with different letters indicate statistically significant differences $(P<0.05$, ANOVA, Tukey multiple comparison).

treatment for 2 and $24 \mathrm{~h}$; on the other hand, Cd exposure caused an significant increase in OASTL specific activity from $2.35 \pm 0.28 \mathrm{U} \mathrm{mg}^{-1}$ protein to $2.8 \pm 0.41 \mathrm{U} \mathrm{mg}^{-1}$ protein after $2 \mathrm{~h}$ and up to $5.2 \pm 0.57 \mathrm{U} \mathrm{mg}^{-1}$ protein after $24 \mathrm{~h}$.

\section{TEM}

Control cells showed a typical ultrastructure, with a cup-shaped chloroplast containing thylakoids arranged along the main axis of the organelle, a central pyrenoid, and electron clear starch grains (Figure 6a). Nucleus and cytoplasm showed a typical organization. No vesiculations were visible in the cytoplasm, which contained electrondense masses of reserve materials.

After a $24 \mathrm{~h} \mathrm{~Pb}$-treatment, mostly of the cells appeared as colonies of four- and more cells with a common cell wall (Figures $6 \mathrm{~b}$ and $\mathrm{c}$ ). The ultrastructural organization showed deformed chloroplasts, with an amoeboid shape, containing thylakoids distributed along the main axis of the organelle, and a central pyrenoid. Numerous lipid droplets and cytoplasm vesicles were visible in the cytoplasm. Nucleus didn't show ultrastructural alterations.

After a $24 \mathrm{~h} \mathrm{Cd}$-treatment, the cells showed altered chloroplast with an amoeboid shape and untidily arranged thylakoids (Figures $6 \mathrm{~d}$ and e). Chloroplasts still contained starch grains. Pyrenoid was lacking or small. Nucleus and

Table 1 The effect of cadmium and lead on chlorophyll $a$ and total chlorophyll contents in Chlorella sorokiniana

\begin{tabular}{|c|c|c|c|c|c|}
\hline \multirow[b]{2}{*}{ Parameter $\left(\mu \mathrm{g} \mathrm{mL}^{-1} \mathrm{PCV}\right)$} & \multirow[b]{2}{*}{ Control } & \multicolumn{2}{|c|}{ Lead } & \multicolumn{2}{|c|}{ Cadmium } \\
\hline & & $2 \mathrm{~h}$ & $24 \mathrm{~h}$ & $2 \mathrm{~h}$ & $24 \mathrm{~h}$ \\
\hline Chl a & $12.65 \pm 0.65^{a}$ & $10.09 \pm 0.35^{b}$ & $3.10 \pm 0.4^{c}$ & $9.10 \pm 0.3^{b d}$ & $2.56 \pm 0.40^{\text {ce }}$ \\
\hline Total Chl & $21.82 \pm 0.6^{a}$ & $15.89 \pm 1.20^{\mathrm{b}}$ & $8.77 \pm 0.35^{c}$ & $15.05 \pm 0.61^{b d}$ & $7.00 \pm 0.80^{c e}$ \\
\hline
\end{tabular}

Data represent mean values $\pm S E(n=3)$. Different letters in the same row mean significance of difference between the treatments $(P<0.05$, ANOVA, Tukey multiple comparison). 


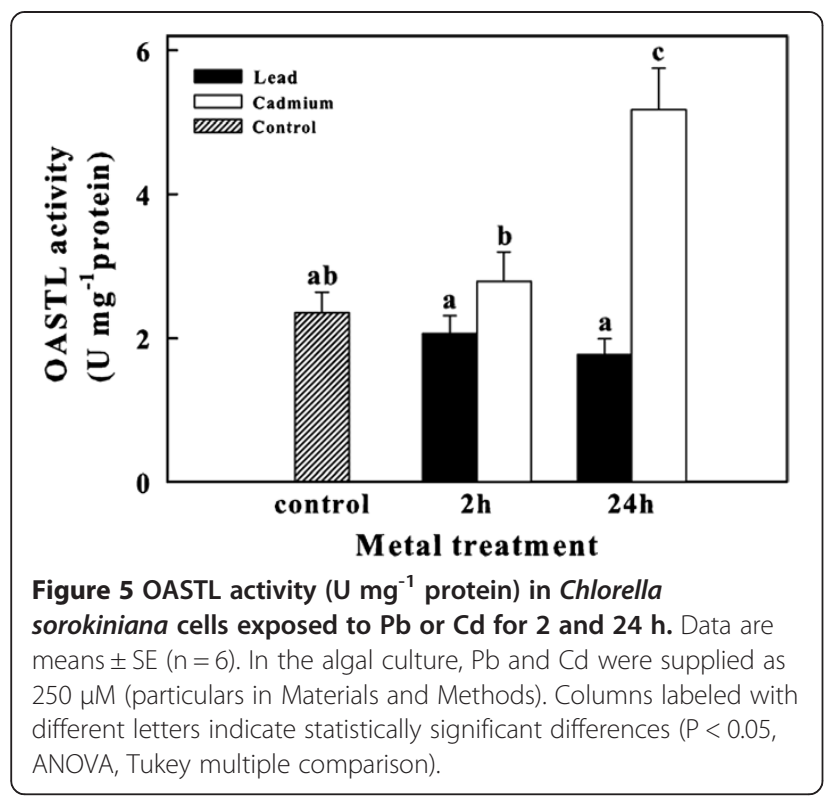

cytoplasm didn't show differences in comparison to control, except for the occurrence of cytoplasm vesicles and multivesicular bodies (Figure 6e).

\section{Discussion}

Despite an increasing literature on biochemical events in response to heavy metals stress in higher plants, little is known about unicellular algae. Microalgae play an important role in the equilibrium of aquatic ecosystems

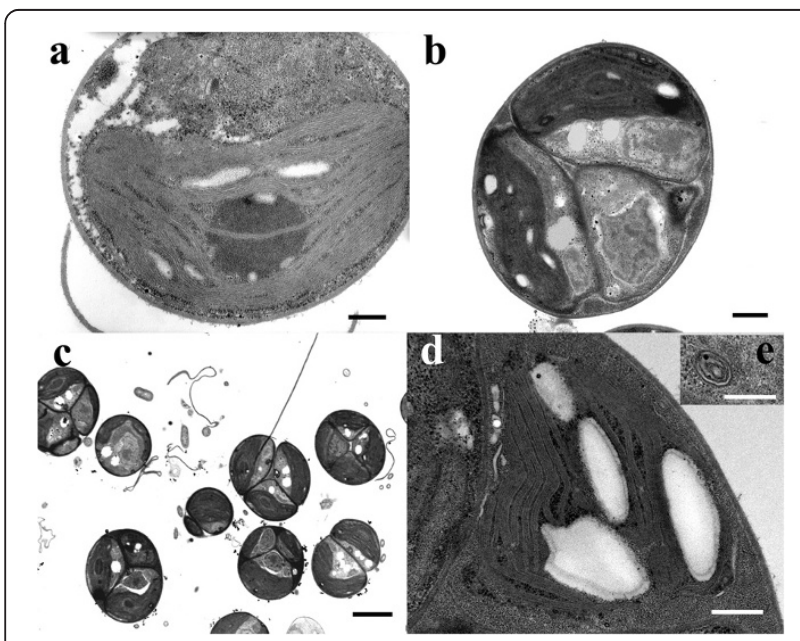

Figure 6 Chlorella sorokiniana TEM micrographs: control (a), $\mathrm{Pb}$-treated $(b, c)$ and $\mathrm{Cd}$-treated $(\mathrm{d}, \mathrm{e})$ culture. $\mathbf{a}$. A cell with a cup-shaped chloroplast containing thylakoids, a central pyrenoid, and electron clear starch grains. $\mathbf{b}$. A colony of algal cells with misshaped chloroplasts, a nucleus, and cytoplasm lipid droplets. c. The typical appearance of a Pb-treated culture with cells organized as colonies. $\mathbf{d}$. A cell with a shape-altered chloroplast still containing thylakoids and starch grains. e. A multivesicular body. Scale bars: $2 \mu$ (c); $500 \mathrm{~nm}(\mathbf{b}, \mathbf{d}) ; 300 \mathrm{~nm}(\mathbf{a}, \mathbf{e})$ and represent highly suitable biological indicators of environmental changes.

We utilized a strain of Chlorella sorokiniana, an unicellular chlorophyte, as a model system for physiological, biochemical and morphological studies on heavy metal stress response. The algal cells were exposed for a short and a long period ( 2 and $24 \mathrm{~h}$ ) to heavy metal such as $\mathrm{Cd}$ and $\mathrm{Pb}(250 \mu \mathrm{M})$.

$\mathrm{Cd}$ and $\mathrm{Pb}$ inhibited the specific growth rate. In $\mathrm{Pb}$ treated samples we observed most of the algal cells grew as colonies and contained plenty of cytoplasm lipid droplets. Probably, Chlorella cells, after first mitosis, continue to divide, forming colonies of four- and more cells with a common cell wall, and only some algae live independently.

The occurrence of adipocyte forms deriving from starch granules and lipids, even after a short time treatment, is regarded as stress symptoms (Lebsky 2004).

Concentric multilamellar/multivesicular bodies were well distinct in Chlorella cells Cd-polluted. These organelles were regarded as accumulation of membranes correlated with incomplete digestion of endocytosed material: double-membrane-bound vesicles arising from endoplasmic reticulum tubes enclose cytoplasm or organelles and coalesce to seal the region in a doublemembrane-bound compartment.

We suggest that the repeated phenomena of encircling and sealing cytoplasmic regions by endoplasmic reticulum tubes might generate the concentric multilamellar bodies in our cadmium exposed samples.

Thompson and Vierstra (2005) reported the autophagic activity of cell vacuoles to destroy the cytoplasm and nucleus. Autophagocytosis phenomena have been reported also for unicellular algae (Reunova et al. 2007).

We suggest that the cytoplasm vesicles, and concentric multilamellar/multivesicular bodies were induced by heavy metal treatment and they might be involved in the transport of metal ions to vacuoles or vesicles and/or in the elaboration of massive newly formed or damaged material.

In Chlorella, $\mathrm{Cd}$ had a much higher effect than $\mathrm{Pb}$ on physiological functions such as photosynthesis and respiration. Particularly, photosynthetic activity resulted strongly compromised by $\mathrm{Cd}$ treatment. According to Neelam and Rai (2003), a possible explanation for Cd effect on photosynthesis could be the inhibition of the PS II as a result of damage of thylakoid membranes and reaction centers. In fact, Chlorella cells showed an ultrastructural alteration in the shape and organization of thylakoids that confirm a damage of the photosynthetic apparatus. Chloroplasts and their arrangement represent a common target of toxic substances in algae and higher plants (Carginale et al. 2004; Nacorda et al. 2007; Basile et al. 2008). The altered chloroplast shape could be a consequence of a perturbation of cation exchange induced by heavy metaltreatment (Basile et al. 2008), while the structural alterations 
of the thylakoid system could depend on the ability of heavy metals to bind to proteins and to interfere with their normal functions, also inducing oxidative damage (Heumann 1987). Moreover, the chloroplast alterations in leaves of tomato exposed to heavy metals were related to an increase in the production of ROS (Gratao et al. 2009). In our experiments, associated to ultrastructural alterations of plastids, we noted a significant reduction of the photosynthetic rate related to a decrease of total $\mathrm{Chl}$ and $\mathrm{Chl} a$ contents that both pollutants $\mathrm{Pb}$ and $\mathrm{Cd}$ caused. The decreases of $\mathrm{Chl} a$ and total Chl indicated a decline in the antenna size of the photosynthetic reaction center complexes. Qiu et al. (2006) showed that in Chlorococcum sp. AZHB the decrease of Chl a correlated to the increasing concentrations of $\mathrm{Cu}$ or $\mathrm{Cd}$ treatment. The decrease of chlorophyll, accompanied by the degradation of the chloroplast structure, in Chlorella heavy metal polluted indicates that the photosynthetic apparatus in these cells could be disrupted.

Therefore, the decrease of growth occurring in the algae $\mathrm{Cd}$ or $\mathrm{Pb}$ treated could be ascribed to the reduction of the photosynthetic activity.

A decrease of soluble protein content was detected in C. sorokiniana cells $\mathrm{Pb}$ - or Cd-treated for $24 \mathrm{~h}$ by 61 and $65 \%$ of the control, respectively. Probably, chlorophylls and proteins, and even the chloroplast proteins, represented an emergency source of nitrogen and sulfur to ensure cell growth. Moreover, the reduction of protein content might also be attributed to the shortage of carbon skeleton resulting from low photosynthetic rate.

The respiratory rate of the alga, under $\mathrm{Pb}$ or $\mathrm{Cd}$ exposure significantly increased. Little is known in literature about heavy metal-induced cellular respiration. Desouky (2011) reported that the respiration of pollutant Chlorella vulgaris cultures was considerably increased by heavy metal exposure: but these studies were conducted in algae treated with high ( 6 and $8 \mathrm{ppm}$ ) and low (2 and $4 \mathrm{ppm}$ ) concentrations of $\mathrm{CoCl}_{2}$ or $\mathrm{NiCl}_{2}$.

The remarkable enhancement of respiratory oxygen consumption in C. sorokiniana cells exposed to $\mathrm{Pb}$ or $\mathrm{Cd}$ could be an adaptive developed strategy to compensate the energy depletion caused by a low photosynthetic activity. C. sorokiniana cells seemed to use respiration to provide more energy to sustain the metabolism as previously reported (Vona et al. 1999).

Most studies regarding oxidative stress responses indicate Cys and GSH as the main antioxidants in the plant cell apart from ascorbate (Foyer and Noctor 2009).

In this study, we reported that in C. sorokiniana cells Cd-treated, OASTL activity enhanced up to 2.2-fold after $24 \mathrm{~h}$, respect to control cells. However, the activity of this enzyme seems to be not influenced by $\mathrm{Pb}$ treatment. The different results on OASTL activity between $\mathrm{Cd}$ and $\mathrm{Pb}$ treatment could depend on the toxicity level of the single metal. Like in the epiphytic moss Scorpiurum circinatum (Carfagna et al. 2011b), the positive relationship concerning OASTL and metal exposure may suggest that in Chlorella cells exists a link between heavy metal tolerance and Cys synthesis. Increased Cys synthesis associated with heavy metals appears to be a necessary response for biosynthesis of GSH and of the other ligands involved in the heavy metal binding.

\section{Conclusion}

The present study provided data on the toxicity of $\mathrm{Pb}$ and $\mathrm{Cd}$ on the cell ultrastructure and physiology of the green-microalga Chlorella sorokiniana. Our data suggest that the toxic effects of the two heavy metals resulted time-dependent to the exposure. Furthermore, the exposure of the algae to $\mathrm{Cd}$ or $\mathrm{Pb}$ compromises the cell growth rate.

These two heavy metals provoke a strong inhibition of photosynthesis but a significant enhancement of respiratory rate, as well as a reduction in the content of the total chlorophylls and of the soluble protein levels. The OASTL activity increase in Cd-treated cells suggests the existence of a link between the metal contamination and cysteine synthesis. Chlorella sorokiniana cells seem to better tolerate high concentrations of $\mathrm{Pb}$ while appear to be more sensitive to $\mathrm{Cd}$ ions. These results provide some additional information about the effects of the heavy metals in microalgae.

\section{Materials and methods}

\section{Strain and culture conditions}

Chlorella sorokiniana Shihira \& Krauss, strain 211/8K (CCAP of Cambridge University), was grown in batch culture at $35^{\circ} \mathrm{C}$, continuously illuminated (Philips TLD $30 \mathrm{~W} / 55$ fluorescent lamps, $250 \mu \mathrm{mol}$ photons $\mathrm{m}^{-2} \mathrm{~s}^{-1}$ ), and flushed with air containing $5 \% \mathrm{CO}_{2}$ at a flow rate of about $80-100 \mathrm{l} \mathrm{h}^{-1}$. The composition of the basal medium ( $\mathrm{pH}$ 6.5) and the growth procedure were previously reported (Vona et al. 2004). The nitrogen source was supplied as $10 \mathrm{mM} \mathrm{KNO}$. Under these conditions, the growth rate constant $(\mu)$, measured on the basis of variations in packed cell volume (PCV), was $3 \mathrm{~d}^{-1}$. For further experiments, cells were collected during exponential growth phase.

\section{Metal treatments}

Experiments were performed using the following analytical grade salts: cadmium chloride hydrate $\left(\mathrm{CdCl}_{2} \cdot \mathrm{H}_{2} \mathrm{O}\right)$ and lead acetate $\left[\mathrm{Pb}\left(\mathrm{CH}_{3} \mathrm{COO}\right)_{2}\right]$. Cell suspensions of C. sorokiniana were exposed to $250 \mu \mathrm{M}$ of the two tested metal salts. Samples of the cell suspension, harvested after $2 \mathrm{~h}$ and $24 \mathrm{~h}$ from the beginning of the metal exposure, were used for different determinations as indicated in the text. Algae cultured in the nutrient medium without heavy metals were used as controls. 


\section{Growth and Packed cell volume (PCV) determination}

Algae growth was measured as PCV by centrifuging a known aliquot of cell suspension in a haematocrit tube at $4000 \times \mathrm{g}$ for $5 \mathrm{~min}$ (Centrifuge Thermo CL10).

The specific growth rate $(\mu)$ was calculated for the exponential growth phase as $\ln \left[\left(\mathrm{PCV}_{\mathrm{t}} / \mathrm{PCV}_{0}\right) / \Delta \mathrm{t}\right]$, where $\mathrm{PCV}_{0}$ is the initial $\mathrm{PCV}, \mathrm{PCV}_{\mathrm{t}}$ is the final $\mathrm{PCV}$, and $\Delta \mathrm{t}$ is the time interval between biomass measurements.

\section{Photosynthetic and respiratory rates}

Photosynthesis and respiration were measured as $\mathrm{O}_{2}$ exchange in a glass biochemical oxygen demand (BOD) water-jacketed bottle equipped with an oxygen electrode (Orion 97-08), connected to an EA 920 ion analyser.

To measure photosynthesis, cells were collected during exponential growth by centrifugation and re-suspended to a final concentration of about $0.5 \mu \mathrm{PCV} \mathrm{mL}{ }^{-1}$ in a fresh basal medium supplemented with $10 \mathrm{mM} \mathrm{NaHCO}$ to prevent carbon limitation, then transferred to the oxygen electrode chamber, illuminated with incandescent light (Philips Comptalux 300 W 13736 E/44, the Netherlands), $1000 \mu \mathrm{mol}$ photons $\mathrm{m}^{-2} \mathrm{~s}^{-1}$, sufficient to achieve full photosynthesis in the alga. Photon flux density inside the culture was measured using a quantum meter with a separate sensor (model Q MSS-SUN) (Apogee Instruments, Logan, UT, USA). The medium in the chamber was magnetically stirred.

To measure respiration, the BOD bottle was obscured by covering it with aluminum foil. Photosynthetic oxygen evolution and respiratory oxygen consumption were expressed as $\mathrm{mmol} \mathrm{O}_{2} \mathrm{~mL}^{-1} \mathrm{PCV} \mathrm{h}{ }^{-1}$. The rate of gross photosynthesis was derived from the algebraic sum of the rate of the net photosynthetic $\mathrm{O}_{2}$ evolution and the rate of respiration.

\section{Chlorophyll content}

The chlorophyll (Chl) content ( $a$ and total) was estimated spectrophotometrically after extraction with $\mathrm{N}$, $\mathrm{N}$-dimethylformamide according to Inskeep and Bloom (1985).

\section{Assay of OASTL activity}

C. sorokiniana cells $(500 \mathrm{~mL}$ of suspension), were harvested by low-speed centrifugation $(4000 \times \mathrm{g}$ for $5 \mathrm{~min})$, re-suspended in cold extraction buffer: $50 \mathrm{mM}$ potassium phosphate buffer ( $\mathrm{pH}$ 7.5), $1 \mathrm{mM}$ dithiothreitol, $10 \mu \mathrm{M}$ pyridoxal 5'-phosphate, and then broken by passing twice through a French pressure cell $(11,000 \mathrm{psi})$. The homogenate was centrifuged (Sorvall RC5C - Sorvall Rotor SS34) at $16,000 \times \mathrm{g}$ for $20 \mathrm{~min}$ at $4^{\circ} \mathrm{C}$, and the clear supernatant was used as crude extract. Enzymatic OASTL activity was determined colorimetrically, measuring the cysteine formed, as described in Carfagna et al. (2011a). One unit $(\mathrm{U})$ of OASTL activity corresponds to the formation of $1 \mu \mathrm{mol}$ of Cys $\mathrm{min}^{-1}$. The OASTL activity was related to the soluble protein content of the samples.

\section{Soluble protein determination}

The protein concentration was determined according to Bradford (1976), using bovine serum albumin as standard.

\section{Ultrastructural observations}

After collection, the algae samples were prepared for Transmission Electron Microscopy (TEM) observations as detailed in Basile et al. (1994). Briefly, after fixation with $3 \%$ glutaraldehyde for $2 \mathrm{~h}$ at room temperature, samples were post-fixed in $1 \% \mathrm{OsO}_{4}$ at $4^{\circ} \mathrm{C}$, before being dehydrated with ethanol. After dehydration, samples were embedded in Spurr's epoxy resin. Ultrathin sections $(60 \mathrm{~nm})$ were cut with a diamond knife on a Supernova microtome and sequentially stained at room temperature with uranyl acetate (3\%) for 12 min and Reynold's lead citrate (2\%) for $8 \mathrm{~min}$. A FEI EM 208S TEM, with an accelerating voltage of $80 \mathrm{kV}$, was employed for observations.

\section{Statistical analyses}

The data were analyzed by two-way analyses of variance (ANOVA) followed by a Tukey test to determine whether significant differences occurred between treatments. Differences were considered significant at $\mathrm{P}<0.05$. All analyses were carried out using SigmaPlot (version 11.0).

\section{Reagents}

All reagents used are of analytical grade and purchased from the Sigma-Aldrich (Milan, Italy). The solutions were prepared with ultrapure water (Millipore). All reagents and chemicals were used without any further purification.

\section{Competing interests}

The authors declare that they have no competing interests.

\section{Authors' contributions}

$S C, A B$ and $W$ carried out the study conception and design, the analysis and the interpretation of data. SC and W performed statistical analysis, drafted and revised the manuscript. NL and GS carried out the biochemical and physiological studies and interpretation of data. AB and SS were involved in the ultrastructural study and interpretation of data. All the authors read and approved the final manuscript.

\section{Author details}

'Dipartimento di Biologia, Università di Napoli Federico II, Via Foria 223, I-80139 Naples, Italy. ${ }^{2}$ CISME, Università di Napoli Federico II, Via Foria 223, I-80139 Naples, Italy.

Received: 23 January 2013 Accepted: 4 April 2013 Published: 8 April 2013

\section{References}

Akira S, Litiana QV, Norihide K, Shigetoh M (2005) Evaluation of the sensitivity of marine microalgal strains to the heavy metals, $\mathrm{Cu}, \mathrm{As}, \mathrm{Sb}, \mathrm{Pb}$ and $\mathrm{Cd}$. Environ Int 31:713-722

Bajguz A (2011) Suppression of Chlorella vulgaris growth by cadmium, lead, and copper stress and its restoration by endogenous brassinolide. Arch Environ Contam Toxicol 60:406-416 
Basile A, Giordano S, Cafiero G, Spagnuolo V, Castaldo-Cobianchi R (1994) Tissue and cell localization of experimentally supplied lead in Funaria hygrometrica (Hedw) using X-ray SEM and TEM microanalysis. J Bryol 18:69-81

Basile A, Sorbo S, Bassi P, Napolitano E, Cogoni AE, Castaldo Cobianchi R (2008) Effects of heavy metals on protonemal development and ultrastructure in populations of the moss Funaria hygrometrica Hedw. (Bryophyta) from a mine and an unpolluted site. Fresen Environ Bull 17:1956-1963

Benavides MP, Gallego SM, Tomaro M (2005) Cadmium toxicity in plants. Braz J Plant Physiol 17:21-34

Bradford MM (1976) A rapid and sensitive method for the quantitation of microgram quantities of protein utilizing the principle of protein-dye binding. Anal Biochem 72:248-254

Carfagna S, Salbitani G, Vona V, Esposito S (2011a) Changes in cysteine and O-acetyl-L-serine levels in the microalga Chlorella sorokiniana in response to the S-nutritional status. J Plant Physiol 168:2188-2195

Carfagna S, Vona V, Salbitani G, Sorbo S, Lanza N, Conte B, Di Martino Rigano V, Cobianchi R, Golia B, Basile A (2011b) Cysteine synthesis in Scorpiurum circinatum as a suitable biomarker in air pollution monitoring. Int J Environ Health 13(5):93-105

Carginale V, Sorbo S, Capasso C, Trinchella F, Cafiero G, Basile A (2004) Accumulation, localisation, and toxic effects of cadmium in the liverwort Lunularia cruciata. Protoplasma 223:53-61

Chader S, Mahmah B, Chetehouna K, Mignolet E (2011) Biodiesel production using Chlorella sorokiniana a green microalga. Rev Energies Renouvel 14(1):21-26

Debelius B, Forja JM, DelValls Á, Lubián LM (2009) Toxicity and bioaccumulation of copper and lead in five marine microalgae. Ecotox Environ Safe 72:1503-1513

Deckert J (2005) Cadmium toxicity in plants: is there any analogy to its carcinogenic effect in mammalian cells? Biometals 18:475-481

Desouky SA (2011) Effect of some natural organic additives on the growth and photosynthesis of pollutant -Chlorella vulgaris Beijer. J Appl Sci Res 7(1):23-32

Foyer CH, Noctor G (2009) A Redox regulation in photosynthetic organisms: signaling acclimation, and practical implications. Antiox Redox Signal 11:861-905

Gratao PL, Monteiroa CC, Rossi ML, Martinellib AP, Peresc LEP, Medici LO, Leae PJ, Azevedoa RA (2009) Differential ultrastructural changes in tomato hormonal mutants exposed to cadmium. Environ Exp Bot 67:387-394

Hanikenne M (2003) Chlamydomonas reinhardtii as a eukaryotic photosynthetic model for studies of heavy metal homeostasis and tolerance. New Phytol 159:331-340

Heumann HG (1987) Effects of heavy metals on growth and ultrastructure of Chara vulgaris. Protoplasma 136:37-48

Inskeep WP, Bloom PR (1985) Extinction coefficients of chlorophyll a and b in N, $\mathrm{N}$-dimethylformamide and 80\% acetone. Plant Physiol 77:483-485

Le Faucheur S, Schildknecht F, Behra R, Sigg L (2006) Thiols in Scenedesmus vacuolatus upon exposure to metals and metalloids. Aquat Toxicol 80:355-361

Lebsky VK (2004) Lipid defense response of Chlorella as theoretical background in wastewater treatment for pollutants. Rev Mex Fis 50:4-6

Nacorda JO, Martinez-Goss MR, Torreta NK, Merca FE (2007) Metal resistance and removal by two strains of the green alga, Chlorella vulgaris Beijerinck, isolated from Laguna de Bay, Philippines. J Appl Phycol 19:701-710

Neelam A, Rai LC (2003) Differential responses of three cyanobacteria to UV-B and Cd. J Microbiol Biotechn 13:544-551

Qiu CE, Kuang QJ, Bi YH, Liu GX, Hu ZY (2006) Response of Chlorococcum sp. AZHB to copper and cadmius stress. Bull Environ Contam Toxicol 77(5):772-778

Reunova YA, Aizdaicher NA, Khristoforovan NK, Reunov AA (2007) Effects of selenium on growth and ultrastructure of the marine unicellular alga Dunaliella salina (Chlorophyta). Russ J Mar Biol 33(2):125-132

Scheidegger C, Behra R, Sigg L (2011) Phytochelatin formation kinetics and toxic effects in the freshwater alga Chlamydomonas reinhardtii upon short- and long-term exposure to lead(II). Aquat Toxicol 101(2):423-429

Sharma P, Dubey RS (2005) Lead toxicity in plants. Braz J Plant Physiol 17:35-52

Sirko A, Gotor C (2007) Molecular links between metals in the environment and plant sulfur metabolism. In: Hawkesford MJ, De Kok LJ (eds) Sulfur in Plants An Ecological Perspective. Springer, Dordrecht, pp 169-195

Soldo D, Hari R, Sigg L, Behra R (2005) Tolerance of Oocystis nephrocytioides to copper: intracellular distribution and extracellular complexation of copper. Aquat Toxicol 71:307-317

Szivak I, Behra R, Sigg L (2009) Metal-induced reactive oxygen species production in Chlamydomonas reinhardtii (Chlorophyceae). J Phycol 45:427-435

Thompson AR, Vierstra RD (2005) Autophagic recycling: lessons from yeast help define the process in plants. Curr Opin Plant Biol 8:165-173
Travieso L, Cañizares RO, Borja R, Benítez F, Domínguez AR, Dupeyrón R, Valiente V (1999) Heavy Metal Removal by Microalgae. Bull Environ Contam Toxicol 62:144-151

Vona V, Di Martino Rigano V, Esposito S, Carillo P, Carfagna S, Rigano C (1999) Growth, photosynthesis, and respiration of Chlorella sorokiniana after $\mathrm{N}$-starvation. Interactions between light, $\mathrm{CO}_{2}$ and $\mathrm{NH}_{4}^{+}$supply. Physiol Plant 105:288-293

Vona V, Di Martino Rigano V, Lobosco O, Carfagna S, Esposito S, Rigano C (2004) Temperature responses of growth, photosynthesis, respiration and $\mathrm{NADH}$ : nitrate reductase in cryophilic and mesophilic algae. New Phytol 163:325-331

Yoshida N, Ikeda R, Okuno T (2006) Identification and characterization of heavy metal-resistant unicellular alga isolated from soil and its potential for phytoremediation. Bioresource Technol 97:1843-1849

doi:10.1186/2193-1801-2-147

Cite this article as: Carfagna et al.: Physiological and morphological responses of Lead or Cadmium exposed Chlorella sorokiniana 211-8K (Chlorophyceae). SpringerPlus 2013 2:147.

\section{Submit your manuscript to a SpringerOpen ${ }^{\odot}$ journal and benefit from:}

- Convenient online submission

- Rigorous peer review

- Immediate publication on acceptance

- Open access: articles freely available online

- High visibility within the field

- Retaining the copyright to your article

Submit your next manuscript at $>$ springeropen.com 